\title{
RABEP1 Gene
}

National Cancer Institute

\section{Source}

National Cancer Institute. RABEP1 Gene. NCI Thesaurus. Code C97751.

This gene is involved in the regulation of both GT Pase activity and endocytosis. 